\title{
Investigation of the Effects of Eucalyptus Extracts on Shelf-Life of Passion Fruit Juice
}

\author{
Habasi Patrick Manzi ${ }^{1}$, Valentin Niyigena ${ }^{2}$, Fabien Matsiko ${ }^{2}$, Theoneste Niyigaba ${ }^{3}$, \\ Gratien Twagirayezu $^{4^{*}}$, Olivier Irumva ${ }^{5}$, Angelique Nyiranshuti ${ }^{6}$ \\ ${ }^{1}$ Department of Occupational and Environmental Health, School of Public Health, Lanzhou University, \\ Lanzhou 730000, Gansu Province, PR China \\ ${ }^{2}$ School of Food Science and Technology, College of Agriculture, Animal Sciences and Veterinary Medicine, \\ BP: 3900, University of Rwanda \\ ${ }^{3}$ Institute of Nutrition and Food Hygiene, School of Public Health, Lanzhou University, \\ Lanzhou 730000, Gansu Province, PR China \\ ${ }^{4}$ School of Environmental and Municipal Engineering, Lanzhou Jiaotong University, Lanzhou 730070, China \\ ${ }^{5}$ School of Eco-Environmental Engineering, Guizhou Minzu University 550025, China \\ ${ }^{6}$ Institute of Food and Bioresources Technology, Dedan Kimathi University of Technology, 10100 Nyeri, Kenya
}

Received: 4 September 2021

Accepted: 6 November 2021

\begin{abstract}
This study was aimed to assess the effects of eucalyptus extracts on the shelf life of passion fruit juice. The pressing and the hydro-distillation approaches were performed to obtain the passion fruit juice and the eucalyptus extracts, respectively. A mixture of passion fruit juice and eucalyptus extracts at different concentrations $(0,10,20,30$, and 40\%) were stored at ambient temperature for 18 days. The yeast and molds (YM), total coliform (TC), and growth of total viable count (TVC) were evaluated every 3 days. Compared to the control group, all treatment groups with eucalyptus extracts inhibited microbial growth and the inhibition increased as time elapsed. Obviously, after 3 days, $40 \%$ concentration was significantly inhibited colon-forming of YM, TC, and TVC by 100, 58.3 and 100\%, respectively. Diversely, $10 \%$ concentrations inhibited their growth by $7.9,5.3$, and $31.5 \%$, respectively. However, On the $18^{\text {th }}$ day, no microorganism colonies formed except for TVC at a concentration of $10 \%$ with an inhibition of $42.2 \%$. This approach can be an efficient method for preserving passion fruit juice, thereby exacerbating the growth of microorganisms.
\end{abstract}

Keywords: eucalyptus extracts, passion fruit juice, total coliform, total viable count, yeast and molds

*e-mail: tgratien0@gmail.com 


\section{Introduction}

Passion fruit (Passiflora edulis) comes from the Passifloraceae family and is an ovoid-shaped fruit native in Brazil that yields a brilliant orange juice with a powerful flavor [1]. It has been found to be widely grown in a variety local area of Rwanda. Passion fruit is a well-known tropical fruit that can be consumed freshly or processed into a variety of other products. In addition, passion fruit is valued not only for producing high-quality squash, but also for flavoring other products. Passion fruit juice is considered as an essential source of minerals and vitamins. Furthermore, passion fruit juice is delicious, nutritious, and rich in vitamin A and contains fair amounts of sodium, magnesium, sulfur, chlorides, and unusually high starch content [2]. The nutrients in the juice are ingested and assimilated by an organism to produce energy, stimulate growth, and maintain life.

Unpreserved fresh passion fruit juice has a short shelf life of a low period compared to preserved juice. Several types of preservatives are employed to increase the shelf life and sustain the quality. However, the artificial preservatives used may induce some harmful effects on consumers' health [3]. Namely, the sulfite preservatives often employed in various fruit juices may induce side effects such as headaches, palpitations, allergies, and possibly cancer [4]. The irradiation approach used for preservation does not make foods radioactive. However, this method may cause changes in food color or texture [5]. The eucalyptus tree is a worldwide dominating tree that may be found ecologically and economically in a broad variety of climatic environments [6]. The genus Eucalyptus comprises around 700 species, with over 300 of them generating volatile oils in their leaves. Essential oils derived from several eucalyptus species are utilized in many domains such as medicine, toiletries, cosmetics, and food [7] and they have revealed potential antimicrobial properties $[8,9]$. The majority of preservatives used today are artificial rather than natural. Several of them are toxic and others have potentially life-threatening side effects. Artificial preservatives can cause serious health hazards such as hypersensitivity, allergy, asthma, hyperactivity, neurological damage, and cancer. Various studies has evinced that several natural preservatives obtained from plants, animals, microbes, and minerals contain antioxidant, antimicrobial, and anti-enzymatic properties [10]. Extracts of plants are promising alternatives to produce healthy food preservatives than artificial chemical production [11]. In the food era, food spoilage microorganisms like yeast are an issue of immense concern because sometimes they might resist physical treatment approaches during juice production [12]. The application of artificial preservatives extends shelf-life; however, they induce side effects to consumers. Demand for passion fruit juices has increased as a result of their health benefits. In recent years, due to changes in diet, social practices and methods of preservation should be improved by using natural preservation since they hold antimicrobial properties and health benefits [10]. Research has recently been performed to develop the natural preservatives in juice $[13,14]$ consumers are currently demanding wholesome, fresh-like, and safe foods without addition of chemically synthesized preservatives. The application of novel natural antimicrobials to assure safety of fresh-cut fruits and unpasteurized juices while preventing quality loss is a promising alternative. The effectiveness of these natural substances added to fruit derivatives has been studied by different researchers. Antimicrobials of animal (lactoperoxidase, lysozyme, and chitosan. However, no study focused on the role of total eucalyptus extracts in exacerbating the growth of food spoilage microorganisms in juice. Therefore, the purpose of this study is to evaluate the effects of the eucalyptus extracts on the shelf life of passion fruit juice at ambient temperature by assessing their impact on the growth of yeast and molds, total coliform, and total viable count.

\section{Methodology}

\section{Processing Passion Fruit Juice}

Fresh, fully mature, and good quality raw passion fruits were purchased from Nyabugogo market (Kigali city, Rwanda). Thereafter, they were carried to the food processing laboratory of the University of Rwanda. Subsequently, they were weighed using the balancing instrument, followed by sorting out undesirable materials such as damaged fruits, rotten fruits, unripened fruits, and any other foreign matter. Herein, all fruits ready to be processed must be well cleaned to avoid infection, damage, and contamination of the final product. During this operation, whole fruits were washed in clean water to remove soil, leaves, and other particles attached to the fruits. Afterward, the passion fruits were sliced into half using stainless steel knives and then opened with a stainless-steel spoon to check for pulp. Juice extraction was done manually via hand pressing, where seeds and juice were separated using a muslin cloth. The white sugar and potable water were added to fresh juice to meet quality standards; it was concentrated on the required Brix level $(11 \%)$ [15]. The obtained juice was pasteurized to inhibit enzymatic activities and kill some micro-organisms at a temperature of $75-80^{\circ} \mathrm{C}$ within $10 \mathrm{~min}$ [16]. Then, the juice was cooled at a temperature of $65^{\circ} \mathrm{C}$ to add the eucalyptus extracts before packing (Fig. 1).

\section{The Extraction from the Eucalyptus Leaves}

The fresh leaves of Eucalyptus data were collected from Kigali Mountain (Nyarugenge district, Rwanda). After that, they were taken to a laboratory to be sorted and sliced into small parts by scissors. These small 
parts were mixed with distilled water (150-200 g in $500 \mathrm{ml}$ ) and then poured into the clevenger apparatus for the distillation process at a high temperature $\left(176^{\circ} \mathrm{C}\right)$. Vaporized distillates were condensed into the water and eucalyptus extracts through a condenser. Therefore, separated eucalyptus extracts were stored in a refrigerator at $-4^{\circ} \mathrm{C}$.

\section{The Evaluation of the Antimicrobial Activities}

The eucalyptus extracts were added to the passion fruit juice at control, $10 \%, 20 \%, 30 \%$, and $40 \%$. After that, a juice with and without eucalyptus extracts was kept at ambient temperature for 18 days for microbiological analysis. Each fruit juice sample was carefully shaken to provide a homogenized solution for the isolation and enumeration of pathogens in the samples. The passion fruit juice was diluted into peptone water. Thereafter, $0.1 \mathrm{ml}$ of dilutions was spread on culture media prepared according to the manufacturer's refer to plate count agar (micro master lot D153-17). Potato dextrose agar (laboratorias conda. pronadisa and $\mathrm{Hi}$ media laboratory pvt. ltd) supplemented with chloramphenicol and on lactose agar (micro master and Hi media laboratory pvt. ltd) for the enumeration of the total viable count, yeasts and molds, and coliforms, respectively. The plates were upside down and incubated at $37^{\circ} \mathrm{C}$ for 3 days. After they grew, colonies were expressed in terms of colony-forming units (CFU)/ $\mathrm{ml}$. Enumeration of CFU and the growth inhibition ratio (GIR) were executed through formulas (1) and (2).

$$
C F U=\frac{\text { Number of colonies } * \text { inverse of dilution }}{\text { inoculum value }}
$$

$$
G I R(\%)=\frac{C F U_{1}-C F U_{2}}{C F U_{1}} \times 100 \%
$$

Where $\mathrm{CFU}_{1}$ and $\mathrm{CFU}_{2}$ are the values in the control and experimental groups, respectively.

\section{Precautions and Statistical Analysis}

All materials used in this study were autoclaved at $121^{\circ} \mathrm{C}$ for $15 \mathrm{~min}$. The working benches, plastic Petri dishes, and pipettes were cleaned and disinfected with $70 \%$ ethanol to avoid cross-contamination during operation and all technics were done aseptically. A mean value and a standard deviation were computed for the collected data. Statistical analysis was performed using SPSS software (SPSS18.0, Germany). The level of significance was set at $P<5 \%$ in all cases.

\section{Results}

\section{Effect of Eucalyptus Extracts on Yeast and Molds}

The impact of eucalyptus extracts on the growth of yeasts in the passion fruit juice is represented in Fig. 2. During this research, investigations revealed that eucalyptus extracts inhibited the development of the YM at all the concentrations $(10,20,30$, or $40 \%)$. The inhibitory effects of the eucalyptus extract against $\mathrm{YM}$ in juice significantly increased with an increase in their concentrations $(\mathrm{P}<0.05)$. For instance, the eucalyptus extracts were raised from $0 \%$ to $30 \%$ on the $6^{\text {th }}$ day of the juice storage induced the count of YM

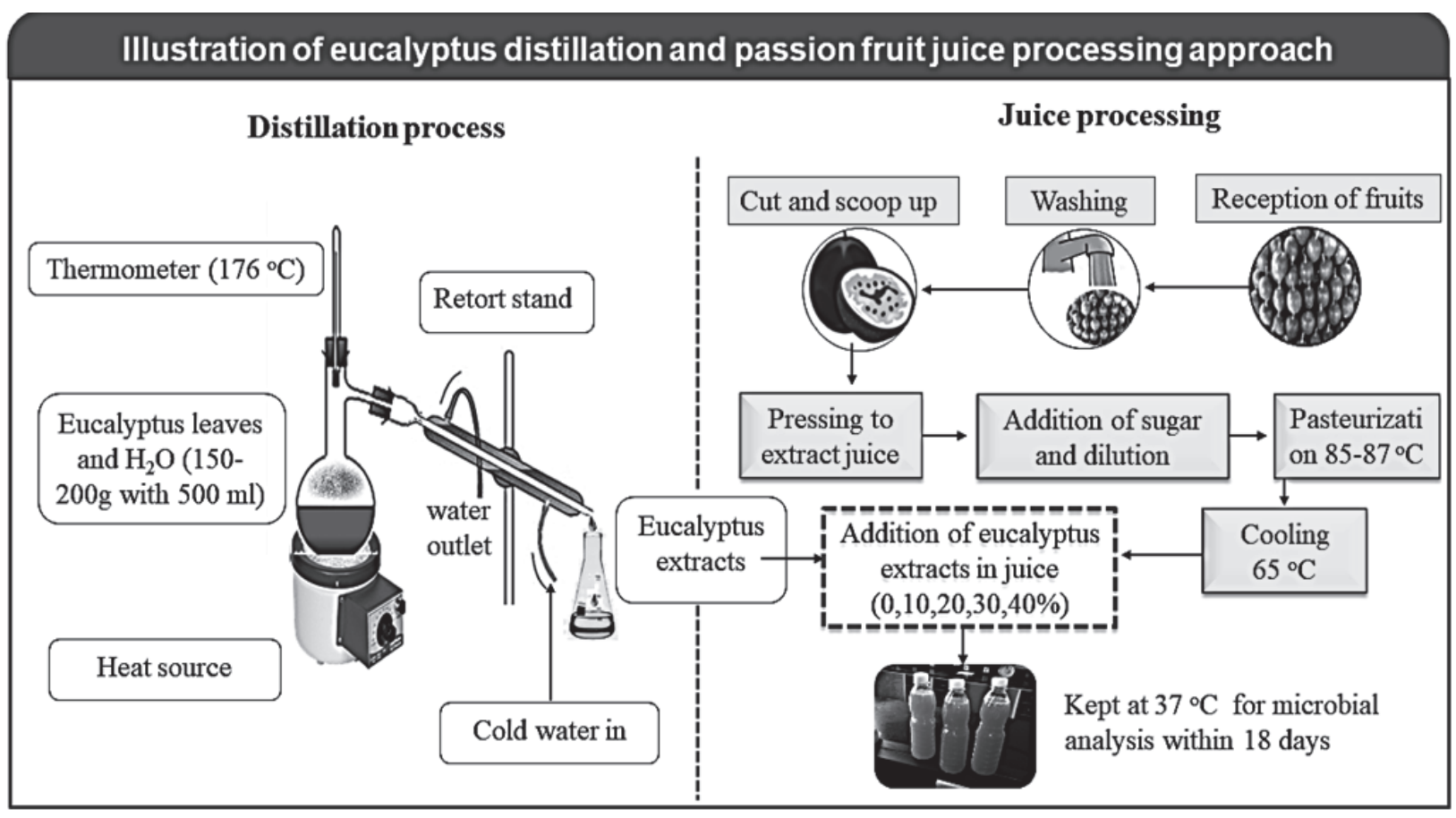

Fig. 1. Extraction of eucalyptus extracts and passion fruit juice processes. 

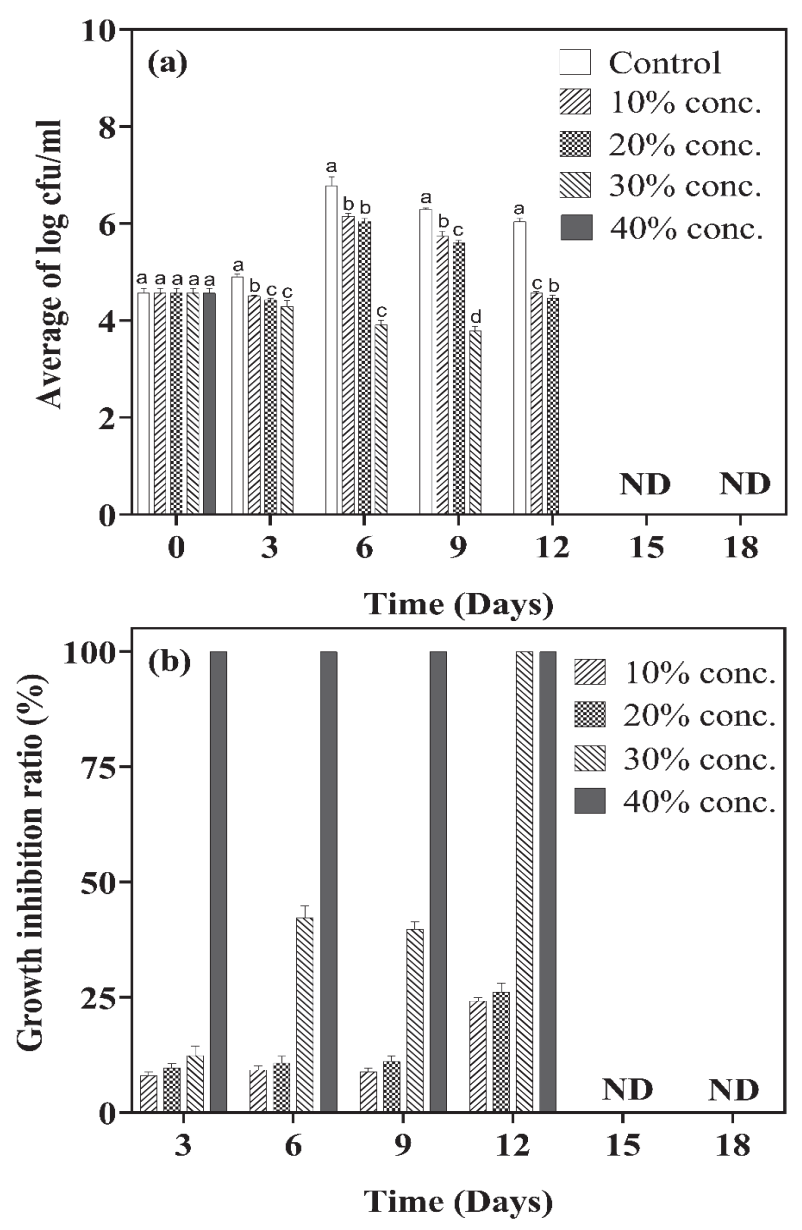

Fig. 2. Effect of the eucalyptus extracts on yeast and molds in passion fruit juice. Growth a) and inhibition ratio b). The letters indicate a significant difference with $P$-value $<0.05$. ND: No growth detected.

to decrease by $3 \log$ units, from $7 \log \mathrm{CFU} / \mathrm{ml}$ to $4 \log$ $\mathrm{CFU} / \mathrm{ml}$. The total inhibition of YM was observed at $40 \%$, and all concentration of eucalyptus extracts after 3 and 12 days, respectively. Similar previous results were observed in a study conducted on the effect of eucalyptus oil on oranges and reported that the antiyeast activity of the eucalyptus extracts is attributed to its high content of oxygenated monoterpenes [17].

\section{Effect of Eucalyptus Extracts on Total Coliform}

Most fruit juices contain sufficient nutrients that could support microbial growth. Water used for juice preparation can be a significant source of microbial contaminants such as coliforms. Commonly, a safe food consumption standard does not allow for the presence of coliform in fruit juice [18]. The trend of eucalyptus extracts' effect on TC is presented in Fig. 3. The inhibitory effects of the eucalyptus extracts against coliform increased with an increase in the levels of the extracts added to the passion fruit juice. The rise of eucalyptus extract from $0 \%$ to $40 \%$ on the $3^{\text {rd }}$ day of the passion fruit juice storage alleviated the count of
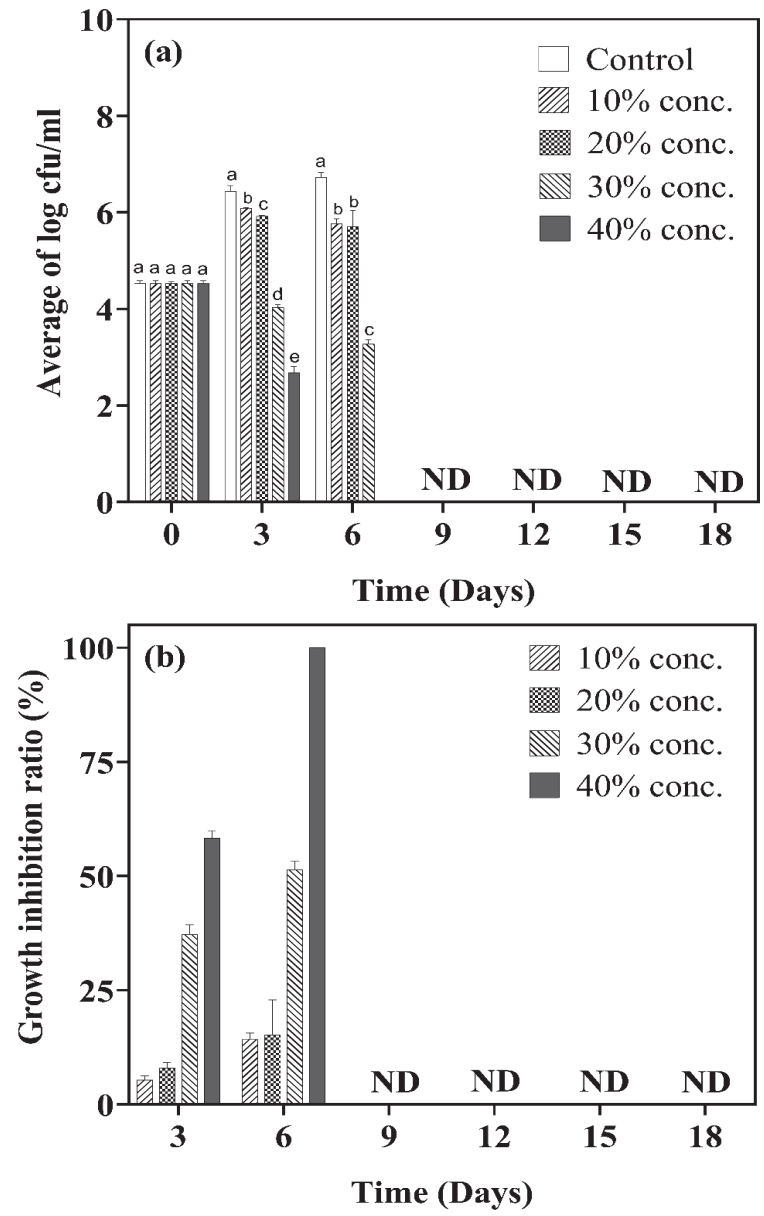

Fig. 3. Effect of eucalyptus extract concentration on total coliform. Growth a) and inhibition ratio b). The letters indicate the significant differences with $P$-value $<0.05$. ND: No growth detected.

TC by $3 \log \mathrm{CFU} / \mathrm{ml}$, from $6.35 \log \mathrm{CFU} / \mathrm{ml}$ to $2.7 \log$ $\mathrm{CFU} / \mathrm{ml}$. The growth of TC was not detected in the juice after 6 days for all concentrations. $30 \%$ and $40 \%$ concentrations evinced the highest inhibition on day 6 with a GIR of $100 \%$.

\section{Effect of Eucalyptus Extracts on Total Viable Count}

As the concentration of eucalyptus extracts increased, the anti-microbial activity also increased. As represented in Fig. 4, the $30 \%$ and $40 \%$ concentrations of eucalyptus extracts have a strong inhibitory effect than $20 \%$ and $10 \%$ concentrations of eucalyptus extract. The TVC count decreased by $3 \log \mathrm{CFU} / \mathrm{ml}$, which is from $6.3 \log \mathrm{CFU} / \mathrm{ml}$ to $2.7 \log \mathrm{CFU} / \mathrm{ml}$ under $20 \%$ eucalyptus extracts on $9^{\text {th }}$ day of the passion fruit juice storage. Over dedicates, the antimicrobial activity tests revealed that the essential oil of eucalyptus has an intense antimicrobial activity, especially against many Gramnegative and Gram-positive bacteria [19]. 30\% and 40\% concentrations were significantly inhibited TVC growth 

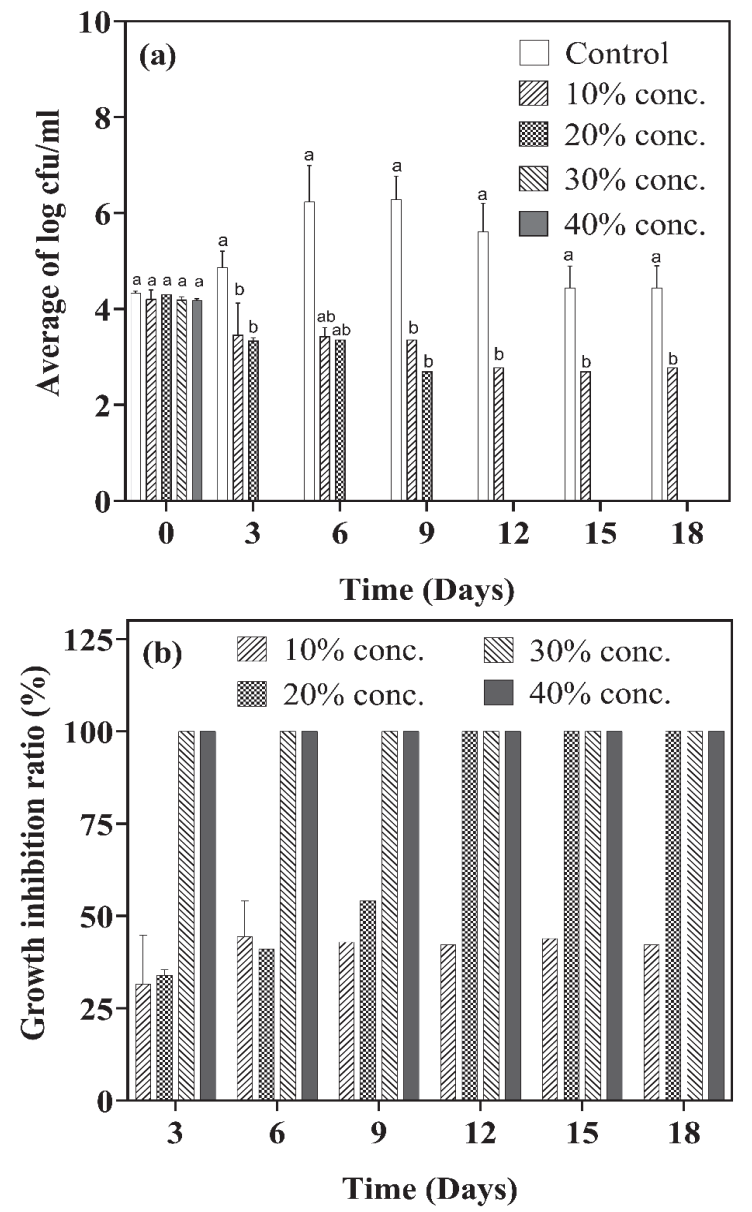

Fig. 4. Effect of eucalyptus extracts concentration on the total viable count in passion fruit juice. Growth a) and inhibition ratio $b$ ). The letters indicate a significant difference with $P$-value $<0.05$. on $3^{\text {rd }}$ day with the highest GIR of $100 \%$, similar to $20 \%$ concentrations on day $12.10 \%$ concentration expresses inhibition along with days. However, it did not induce inhibition ultimately and its GIR on the last day was $42.2 \%$.

\section{Comparative Study of the Effect of Eucalyptus Extracts on both TC, YM, and TVC}

The passion fruit juice was analyzed for enumeration and identification of microbiological contaminants. The sample was cultured using the spread plate method as the best for bacterial enumeration of food samples. Before observing a TVC on plate count agar, TC on lactose broth with agar I and YM on potato dextrose broth with agar I. All incubated plates were maintained at the requisite time and temperature $37^{\circ} \mathrm{C}$ for $24-48 \mathrm{hrs}$. The mean number of colonies counted was expressed as colony forming units $(\mathrm{CFU}) / \mathrm{ml}$. The results in Fig. 5 showed that the TC is more resistant to the eucalyptus extracts than YM and TVC at $40 \%$ concentration of eucalyptus extracts. However, when the level increased from $0 \%$ to $40 \%$ on the $3^{\text {rd }}$ day of the juice storage, the count of TC decreased by $3 \mathrm{log} \mathrm{CFU} / \mathrm{ml}$, from $6.35 \mathrm{log}$ $\mathrm{CFU} / \mathrm{ml}$ to $2.7 \log \mathrm{CFU} / \mathrm{ml}$.

\section{Discussion}

As initial and final count of microorganisms represented in Table 1, microorganism growth decreased by eucalyptus extracts. In addition, the comparison of our results with other previous research works on the effect of eucalyptus extracts on the growth

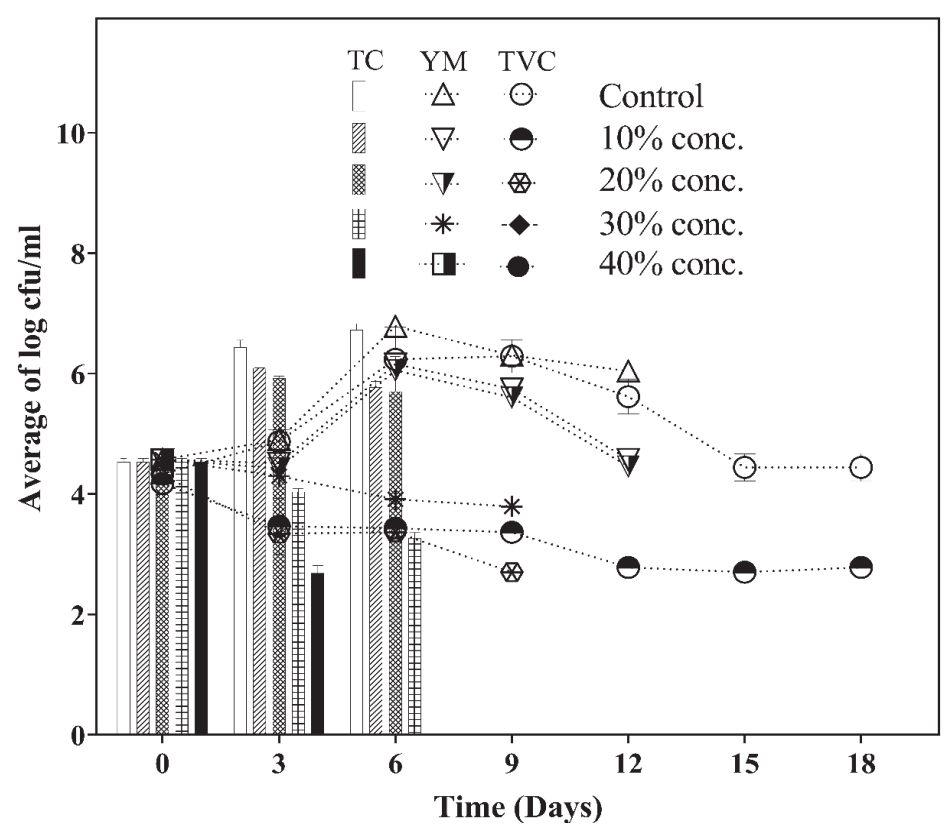

Fig. 5. Comparison of effects of the eucalyptus extracts on all types of microorganisms investigated in this study. TC: total coliform, YM: yeast and molds, TVC: total viable count. 
Table 1. Initial and final microorganism colony-forming from stored passion fruit juice with different concentrations of eucalyptus extracts.

\begin{tabular}{|c|c|c|c|c|}
\hline \multirow{3}{*}{ Period } & \multirow{2}{*}{$\begin{array}{c}\text { Eucalyptus extracts } \\
\text { dosages }\end{array}$} & \multicolumn{3}{|c|}{ Microorganisms' growth (Average log cfu/ml) } \\
\cline { 2 - 5 } & Control & $4.569 \pm 0.057$ & $4.533 \pm 0.031$ & Total viable count (TVC) \\
\hline \multirow{4}{*}{ Initial day } & $10 \%$ conc. & $4.569 \pm 0.057$ & $4.533 \pm 0.031$ & $2.887 \pm 1.443$ \\
\cline { 2 - 5 } & $20 \%$ conc. & $4.569 \pm 0.057$ & $4.533 \pm 0.031$ & $4.207 \pm 0.110$ \\
\cline { 2 - 5 } & $30 \%$ conc. & $4.569 \pm 0.057$ & $4.533 \pm 0.031$ & $2.436 \pm 1.436$ \\
\cline { 2 - 5 } & $40 \%$ conc. & $4.569 \pm 0.057$ & $4.533 \pm 0.031$ & $2.793 \pm 1.396$ \\
\hline \multirow{3}{*}{ Final day } & Control & - & - & $4.651 \pm 0.129$ \\
\cline { 2 - 5 } & $10 \%$ conc. & - & - & $0.926 \pm 0.926$ \\
\cline { 2 - 5 } & $20 \%$ conc. & - & - & - \\
\cline { 2 - 5 } & $30 \%$ conc. & - & - & - \\
\hline
\end{tabular}

of different microorganisms was summarized in Table 2 . A $50 \%$ extract of E.globulus leaves has antibacterial activity against oral pathogenic microorganisms with minimum inhibitory concentration (MIC) values ranging from $0.20 \mu \mathrm{g} / \mathrm{mL}$ to $6.25 \mu \mathrm{g} / \mathrm{ml}$ [20]. Moreover, the extracts from dried leaves of E. globules show appreciable antibacterial activity against S.mutans Ingbritt and P.gingivalis ATCC 33277 (causes dental caries and periodontal disorders) with (MICs) values 125 and $6.25 \mu \mathrm{g} / \mathrm{ml}$; the dried residue of methanolic extract of E. globulus leaves showed antimicrobial activity against Staphylococcus aureus, Escherichia coli, Pseudomonas aeruginosa, and Candida albicans with a minimum inhibitory concentration of 5.0, 10.0, $1.25 \mathrm{mg} / \mathrm{ml}$, respectively [21]. Eucalyptus globulus is used as a traditional treatment for diabetes since the study revealed the incorporation of E.globulus in the diet $(62.5 \mathrm{~g} / \mathrm{kg})$ and drinking water $(2.5 \mathrm{~g} / \mathrm{l})$ reduced the hyperglycemia and associated weight loss of streptozotocin treated mice [22]. The essential oil extracted from the leaves of E. globulus is known to be a rich source of traditional medicines with a variety of biological activities and it is widely used to treat pulmonary tuberculosis and antiseptic agent, especially in the treatment of upper respiratory tract infections and certain skin diseases [23] and also used as a disinfectant [24], antioxidant agent [25]. Eucalyptol 1,8 cineole is a significant constituent present in the volatile oil of Eucalyptus and it is a potent inhibitor of cytokines [26], which means to be suitable for long-term treatment of airway inflammation in bronchial asthma and other steroid-sensitive disorders [27]. Therefore, eucalyptus extracts can be used in foods and drinks at a desirable

Table 2. Comparison between the effect of eucalyptus extracts on the growth of different microorganisms in this study and previously reported studies.

\begin{tabular}{|c|c|c|c|c|c|c|c|}
\hline \multirow{2}{*}{ Food/ medium } & \multicolumn{3}{|c|}{ Eucalyptus extracts } & \multirow{2}{*}{$\begin{array}{l}\text { Exposure } \\
\text { Period }\end{array}$} & \multirow{2}{*}{$\begin{array}{l}\text { Organisms test } \\
\text { for growth }\end{array}$} & \multirow{2}{*}{ Result } & \multirow{2}{*}{ Ref. } \\
\hline & Form & Color & Concentrations & & & & \\
\hline Apples and oranges & Liquid & Clear & $\begin{array}{c}1.125,2.25,4.5 \\
\mathrm{mg} / \mathrm{L}\end{array}$ & 8 days & Yeast & Inhibition & {$[17]$} \\
\hline $\begin{array}{c}\text { Nutrient, BHI, and TS } \\
\text { broths }\end{array}$ & Powder & - & $1-31 \mathrm{mg} / \mathrm{L}$ & $\begin{array}{l}2 \text { days } \\
7 \text { days }\end{array}$ & $\begin{array}{c}\text { Gram-positive } \\
\text { bacteria } \\
\text { Fungus }\end{array}$ & Inhibition & {$[37]$} \\
\hline MHB, PDB & Liquid /vapor & - & $0.27-36 \mathrm{mg} / \mathrm{ml}$ & 2 days & $\begin{array}{l}\text { Bacterial, fungal, } \\
\text { and yeast strains }\end{array}$ & Inhibition & {$[38]$} \\
\hline Sweet potatoes, bread & Liquid & - & - & 11 days & Pests & $\begin{array}{l}\text { Protection } \\
\text { against pests }\end{array}$ & [39] \\
\hline Passion fruit juice & Liquid & Green & $0,10,20,30,40 \%$ & 18 days & $\begin{array}{l}\text { Yeast and molds } \\
\text { Total coliform } \\
\text { Total viable count }\end{array}$ & Inhibition & This study \\
\hline
\end{tabular}


range to avoid the growth of some micro-organisms and enhance consumers' health.

The high rate of food degradation is due to contamination with microorganisms, which is a result of the fact that microorganisms have colonized the whole environment in which humans live [28]. Juice extracted directly from passion fruit is squeezed from crushed material to include a considerable amount of pulp [29]. Juice extracted from fruits is acidic, and the high moisture content is responsible for the growth of yeast and bacteria. Yeasts can grow at low $\mathrm{pH}$, high sugar concentration and low water activity. Fruit juices are generally rich in simple carbohydrates, and complex nitrogen sources and hence are ideal substrates for yeasts [30]. The normal changes to be expected in raw fruit juices at room temperature are an alcoholic fermentation by yeast followed by the oxidation of alcohol and fruit acid by film yeast or mold growing on the surface or the oxidation of alcohol to acid acetic acid bacteria are present [31].

Over 110 species of yeasts have been reported to be associated with food and food products [32]. Generally, there are various techniques to prevent pathogenicity and nonpathogenic microflora, such as chilling, freezing, water activity, modified atmosphere packaging, pasteurization, non-thermal physical methods, and natural antimicrobials [33]. Thermal processing is the most often used method for inactivating microorganisms and enzymes in order to extend the shelf life of fruit juices. However, loss of original taste and flavor compounds occur in fruit juices and these adverse effects have motivated a great interest in the development of new technology that offers advantages of using low processing temperatures, low energy consumption and high retention of nutritional and sensory properties of the food and improving its microbiological quality [34]. Chemical additives can cause harm to some people who are hypersensitive and allergic.

Furthermore, people believe that low levels of chronic toxicity and disease may be caused by exposure to some artificial chemicals [35]. The eucalyptus extracts have different tastes and odor depends on eucalyptus species. Their application for juice preservation should be tested via sensory evaluation to meet appropriate taste and odor to consumers [36]. Moreover, analysis of their effects on juice nutrients contents may be considered to be applied.

\section{Conclusion and Future Outlooks}

This work revealed that eucalyptus extracts could be used as a potential antimicrobial compound against juice spoilage yeasts and the growth of aerobic mesophilic bacteria and coliforms. The inhibition of microbial growth increased with the increase of eucalyptus extracts concentration and time. Further research might be necessary to identify active preservative ingredients in the eucalyptus extracts and evaluate the effects of identified active ingredients on selected Yeasts and Molds, Coliforms, and other microbial species rather than focusing on focusing on microbial groups. This is the basic aspect and further research is required for assessing their effects on the nutrient's contents of juices.

\section{Conflicts of Interest}

The authors declare no conflict of interest.

\section{Acknowledgment}

We express our sincere gratitude to the University of Rwanda which allow us to conduct this study.

\section{References}

1. FEVARI A.D., FEVARI R.D., BROERING M.F., BOUSFIELD I.T., GOSS M.J., MULLER S.P., PEREIRA R.O., SILVA A.M.O., MACHADO I.D., QUINTÃO N.L.M., SANTIN J.R. Effects of passion fruit peel flour (Passiflora edulis f. flavicarpa O. Deg.) in cafeteria diet-induced metabolic disorders. Journal of Ethnopharmacology, 250, 112482, 2020.

2. THOKCHOM M., GOUTAM R. Production preference and importance of passion fruit (Passiflora edulis): a review. Journal of Agricultural Engineering and Food Technology , 4 (1), 27, 2017.

3. KALPANA V.N., RAJESWARI V.D. Preservatives in Beverages: Perception and Needs. In Preservatives and Preservation Approaches in Beverages (Vol. 15, pp. 1-30). Elsevier, 2019.

4. DWIVEDI S., PRAJAPATI P.,VYAS N., MALVIYA S., KHARIA A. A review on food preservation: methods, harmful effects and better alternatives. Asian Journal of Pharmacy and Pharmacology, 3 (6), 193, 2017.

5. SHARMA, SANJAY. Food Preservatives and their harmful effects. International journal of scientific research publications, 5 (4), 1, 2015.

6. ZOUHIR A., JRIDI T., NEFZI A., BEN H.J., SEBEI K. Inhibition of methicillin-resistant Staphylococcus aureus (MRSA) by antimicrobial peptides (AMPs) and plant essential oils. Pharmaceutical Biology, 54 (12), 3136, 2016.

7. MARZOUG H.N.B, ROMDHANE M., LEBRIHI A., MATHIEU F., COUDERC F., ABDERRABA M., KHOUJA M.L., BOUAJILA J. Eucalyptus oleosa essential oils: chemical composition and antimicrobial and antioxidant activities of the oils from different plant parts (stems, leaves, flowers and fruits). Molecules, 16 (2), 1695, 2011.

8. GEBRE T., ADDIS G., LEMMA H., GEMEDA N., DEBELLA A., AYANA D., HAILU Y. In-vitro antibacterial activity of Cymbopogon citratus (DC.) Stapf. and Eucalyptus globulus Labill. Ethiopian Journal of public health nutrition, 2 (1), 2020.

9. FISCHER B., ELOIR P.G., FELTES G., GRIEP P., JUNGES A., PAROUL N., CANSIAN R.L. Antioxidant 
and antimicrobial properties of eucalyptus leaf extract obtained using pressurized ethanol. Brazilian Journal of Development, 6 (10), 74499, 2020.

10. AKHTAR S., ISMAIL T., FRATERNALE D., SESTILI P. Pomegranate peel and peel extracts: Chemistry and food features. Food Chemistry, 174, 417, 2015.

11. KAMALA K.P., AKHILA S., SRINIVASA RY., RAMA D.B. Alternative to Artificial Preservatives. Systematic Reviews in Pharmacy, 10 (1), 99, 2019.

12. ISMAIL M.A. Inhibitory Effects of Na-Hypochlorite and Heating on the Mycobiota Associated with Fruits or Juice of Passion (Passiflora edulis Sims) in Uganda. Mycobiology, 34 (2), 92. 2006.

13. RAYBAUDI-MASSILIA R.M., MOSQUEDA-MELGAR J., SOLIVA-FORTUNY R., MARTÍN-BELLOSO O. Control of Pathogenic and Spoilage Microorganisms in Fresh-cut Fruits and Fruit Juices by Traditional and Alternative Natural Antimicrobials. Comprehensive Reviews in Food Science and Food Safety, 8 (3), 157, 2009.

14. PANDEY A., NEGI P.S. Use of Natural Preservatives for Shelf Life Extension of Fruit Juices. Fruit Juices: Extraction, Composition, Quality and Analysis, 571, 2018.

15. BARERRA J.W.B., TRINIDAD K.A.D., PRESAS J.A. Hand pollination and natural pollination by carpenter bees (Xylocopa spp.) in Passiflora edulis Sims. f. flavicarpa Deg.(yellow passion fruit). Journal of Apicultural Research, 1, 2020.

16. DAUTHY M.E. Fruit and vegetable processing. Food and Agriculture Organization of the United Nations. Rome, 1995.

17. TYAGI A.K., BUKVICKI D., GOTTARDI D., TABANELLI G., MONTANARI C., MALIK A., GUERZONI M.E. Eucalyptus essential oil as a natural food preservative: in vivo and in vitro antiyeast potential. BioMed Research International, 2014, 969143, 2014.

18. ALERU C.P., AGI V.N., NJOKU K. Bacterial Assessment of Unpasteurized Fruit Juices Sold in Port Harcourt, Nigeria. Journal of Applied Life Sciences International, 23 (5), 1, 2020.

19. SABO V.A., KNEZEVIC P. Antimicrobial activity of Eucalyptus camaldulensis Dehn. plant extracts and essential oils: A review. Industrial crops and products, 132, 413. 2019.

20. AHONSI, ABDULKARIM S., EMOGHENE. Antimicrobial Activity of Eucalyptus globulus and Prunus dulcis Oils Against Selected Pathogenic Strains. International Journal of Health, Nursing \& Medicine, 23, 2019.

21. HARDEL D., SAHOO L. A review on phytochemical and pharmacological of Eucalyptus globulus: a multipurpose tree. International Journal of Research in Ayurveda Pharmacy, 2 (5), 1527, 2011.

22. GODGHATE A.G., SWANT R.S. Secondary metabolites determinations qualitatively from bark of Butea monosperma and Eucalyptus globulus. International Journal of Science, Environment, 3 (2), 497, 2014.

23. KAUR G., MOHIUDDIN I., AULAKH J.S. An approach on phytochemistry and pharmacological studies of Eucalyptus globulus plant parts. Research Journal of Material Sciences, 5 (4), 1, 2017.

24. GHOSHAL G., SINGH D. Synthesis and characterization of starch nanocellulosic films incorporated with Eucalyptus globulus leaf extract. International Journal of Food Microbiology, 332, 108765, 2020.
25. GÖGER N., KARACA N., ALTINBAŞAK B.B., DEMIRCI B., DEMIRCI F. In vitro antimicrobial, antioxidant and anti-inflammatory evaluation of Eucalyptus globulus essential oil. Natural Volatiles Essential Oils, 7 (3), 1, 2020.

26. MIRKE N.B., SHELKE P.S., MALAVDKAR P.R., JAGTAP P.N. In vitro protein denaturation inhibition assay of Eucalyptus globulus and Glycine max for potential antiinflammatory activity. Innovations in Pharmaceuticals and Pharmacotherapy, 8 (2), 28, 2020.

27. JUERGENS U.R., STOBER M., VETTER H. Inhibition of cytokine production and arachidonic acid metabolism by eucalyptol (1.8-cineole) in human blood monocytes in vitro. European journal of medical research, 3 (11), 508, 1998.

28. MOSTAFIDI M., SANJABI R.B., SHIRKHAN F., ZAHEDI M.T. A review of recent trends in the development of the microbial safety of fruits and vegetables. Trends in Food ScienceTechnology, 103, 321, 2020.

29. NDUKWE O.O., BAIYERI P.K. Fruit and Juice Metric Characteristics of Two Yellow Passion Fruit (Passiflora edulis Degener) Genotypes Grown in Southeastern Nigeria. Notulae Scientia Biologicae, 11 (3), 422, 2019.

30. BEVILACQUA A., CORBO M.R., SINIGAGLIA M. Selection of yeasts as starter cultures for table olives: a step-by-step procedure. Frontiers in Microbiology, 3, 194. 2012.

31. AKPAN U.G., KOVO A.S. Preservation of passion fruit juice. Leonardo Journal of Sciences, 7, 17. 2005.

32. PATIL S., VALMDRAMIDIS V.P., TIWARI B.K., CULLEN P.J., BOURKE P. Quantitative assessment of the shelf life of ozonated apple juice. European Food Research Technology, 232 (3), 469, 2011.

33. ANEJA K.R., DHIMAN R., AGGARWAL N.K., ANEJA A. Emerging preservation techniques for controlling spoilage and pathogenic microorganisms in fruit juices. International Journal of Microbiology, 2014, 2014.

34. MOSQUEDA-MELGAR J., ELEZ-MARTÍNEZ P., RAYBAUDI-MASSILIA R.M., MARTÍN-BELLOSO O. Effects of pulsed electric fields on pathogenic microorganisms of major concern in fluid foods: a review. Critical Reviews in Food Science and Nutrition, 48 (8), 747, 2008

35. AWUCHI C.G., TWINOMUHWEZI H., IGWE V.S., AMAGWULA I.O. Food Additives and Food Preservatives for Domestic and Industrial Food Applications. Journal of Animal Health, 2 (1), 1, 2020.

36. HYLDGAARD M., MYGIND T., MEYER R.L. Essential oils in food preservation: mode of action, synergies, and interactions with food matrix components. Frontiers in microbiology, 3, 12, 2012.

37. TAKAHASHI T., KOKUBO R., SAKAINO, M. Antimicrobial activities of eucalyptus leaf extracts and flavonoids from Eucalyptus maculata. Letters in applied microbiology, 39 (1), 60. 2004.

38. TYAGI A. K., MALIK A. Antimicrobial potential and chemical composition of Eucalyptus globulus oil in liquid and vapour phase against food spoilage microorganisms. Food Chemistry, 126 (1), 228, 2011.

39. MARCEL, S. Use of essential oils as new food preservatives (Case: Eucalyptus grandis and Eucalyptus crebra). Journal of Plant Science and Phytopatholog, 2, 083, 2018. 